\title{
Editorial
}

\section{Importance to understand Ritusandhi- The time to Build bridges before flood}

In Ayurveda there are two ways to maintain healthy state of individual; 'Swathhasya Swasthya Rakshanam' means to secure the healthy state by following certain set of regime like Ritucharya( seasonal regime ), Dincharya ( daily rotine), Ratricharya ( night regime), Sadvritta( good conduct) etc. and the second one is 'Aturasya Vikar Prashamnam' means to treat the disease.

Ritu is from the root 'R' means "to go" According to Rotha; Ritu meant time, suitable time proper time for Sacrifice. Mainer Williams records the meaning as: fixed time for sacrifice, epoch, season, fixed rule, and given the meaning of ' $\mathrm{R}$ ' as bringing about a continuity. In ancient text whole year is divided in to two Aayan, i.e; Uttarayan and Dakshinayan. this division is based on celestial position. Again each Ayan is divided in three Ritus. Each Ritu comprises of two months. The festivals of Indian culture are very scientific and are indirectly linked to directly or indirectly link with the health. In addition, the festivals of particular season have own extraordinary significance. Since the changes in those seasons also affect human health, it is very important to have knowledge of the changes in the seasons. If we have the necessary knowledge the seasonal variation, we can prevent the health hazards caused by such seasonal changes. Recently we celebrate the festival of Vasant Panchmi in February which indicates arrival of season Vasant. This means that winter is coming to an end and spring is coming. The current period is the time between the two seasons is known as Ritusandhi. In Ayurveda classics the description of Ritusandhi ${ }^{1}$ (inter Seasonal period) is well described. It defined as the junction of two Ritus or the seven days at the end and commencement of the Ritus (seasons) is known as Ritusandhi. This is the time in which unhealthy changes take place in the body and best time to use the recipes to adapt gradually of coming season.

The idea of Ritu Sandhi is first seen in Vedic literature itself. More than once the Vedic texts speak of Ritu Mukha. The exhilarated shouts of peacocks mingled with the notes of Swans, the new blue lotuses with the Kadambas still raining their flowers forms an example of "Varsa Sharad Sandhi". In Samhita Kala, Acharya Charak and Acharya Sushruta didn't mention about this concept. Acharya Vagbhatta for the first time mentioned this concept in 
Ritucharya chapter. Acharya Sharngdhar more precisely defines this concept for the months of Kartika and Margshirsha, and coined it as Yamadamstra Kala, and advised restricted diet and activity.

The detailed description of Ritucharya (seasonal regime) found in Ayurveda. Loka Purush Satmy $a^{2}$ is an important concept in our text. which signifies that individual and the environment is one and the same thing. So, if there is any change in environment, then it will certainly disharmonize the individuals. In addition, this is a peak time when the body is affected by various diseases due to seasonal changes. That's why In Ayurveda texts, this period is called Yamdrashta ${ }^{3}$. Hence it is necessary to take preventive measures to maintain health of individuals. So, Ritu Sandhi is essential to combat that imbalance and to harmonize the individual according to the environment. During the period of Ritusandhi, it is advised to strict precaution for the prevention of seasonal disorders. Also, it is advised to the regimen of the proceeding season should be discontinued gradually and that of the succeeding season regimen adopt gradually ${ }^{4}$. For example, In Shishir Ritu people have strong digestive fire, so use of heavy food made of freshy harvested corn, Jeggary, sweet, sour substances should have habit to decrease gradually ${ }^{5}$. While in Vasant Ritu digestive fire is diminished, so food which are easily digestible should habit to increase gradually in the period between the junction of Shishira Ritu(winter) and Vasant Ritu ( spring).

Ritu has its influence from the time of conception until death. To maintain the proper health and to tolerate Kalaja Vyadhi ${ }^{6}$ it is essential to follow Ritu Satmya. Ritu Satmya is the regimen told for the specific Ritu for specific duration. The strength and luster of human beings who knows the suitable diet and regimen for every season and practices accordingly are enhanced. Regimen and diets having opposite qualities of the habitat of the individuals causes the imbalance of Dosha. But habituated things if to be given up then it is to be done slowly and gradually otherwise it may lead to Asatmyaja Roga.In this context, For the prevention of seasonal disorders, there is depth description of schedule for the give up regime related to seasonal changes for the maintain the health of individual. A wise person should give up by and by unwholesome practices to which he is addicted and he should correspondingly adopt ones which are wholesome ${ }^{7}$. On the first day one should give up a quarter of the unwholesome practice (still maintaining $3 / 4$ of it) and correspondingly adopt a quarter of wholesome. On the second day half of the unwholesome practice is to be given up and half of the wholesome one is to be adopted; this is to be continued for the third day also. On the fourth day, $3 / 4$ of the unwholesome practice is to be given up and $3 / 4$ of the wholesome 
one is to be adopted. This process is to be continued on the 5th and 6th day also. The process of giving up of the unwholesome practice and adoption of the wholesome practice is completed fully on the 7 th day.

For the prevention of the diseases produces in the period of Ritusandhi one should adopt the Rasayana Therapy (rejuvenation), immune enhancer drugs like Guduchi( Tinospora cordifolia.willd.), Haridra( Curcuma longa Linn.), Yashtimadhu, (Glycyrrhiza glabra Linn) ,Ashwagandha( Withania somnifera - (L.)Dunal.) can helps to increase the immunity of the body leads to prevent the illness produce by the seasonal changes.

\section{Jitendra Varsakiya, ${ }^{1}$ T.S. Dudhamal, ${ }^{2}$ N.N. Tiwari ${ }^{3}$}

${ }^{1}$ Assistant Professor, PG Department of Kayachikitsa, CBPACS, New Delhi, ${ }^{2}$ Associate Professor and Head, Dept. of Shalya Tantra, IPGT \& RA, Gujarat Ayurved University, Gujarat, Jamnagar, India, ${ }^{3}$ Ex. Professor and HOD, Dept of Dravyaguna, Ayurveda campus IOM, TU, Kathmandu, Nepal

\section{How to cite this article:}

Varsakiya J, Importance to understand Ritusandhi- The time to Build bridges before flood , The Healer Journal, 2021;2(1):1-9.

Submitted: 17.01.2021 Received: 19.01.2021 Revised: 25.01.2021 Accepted: 26.01.2021

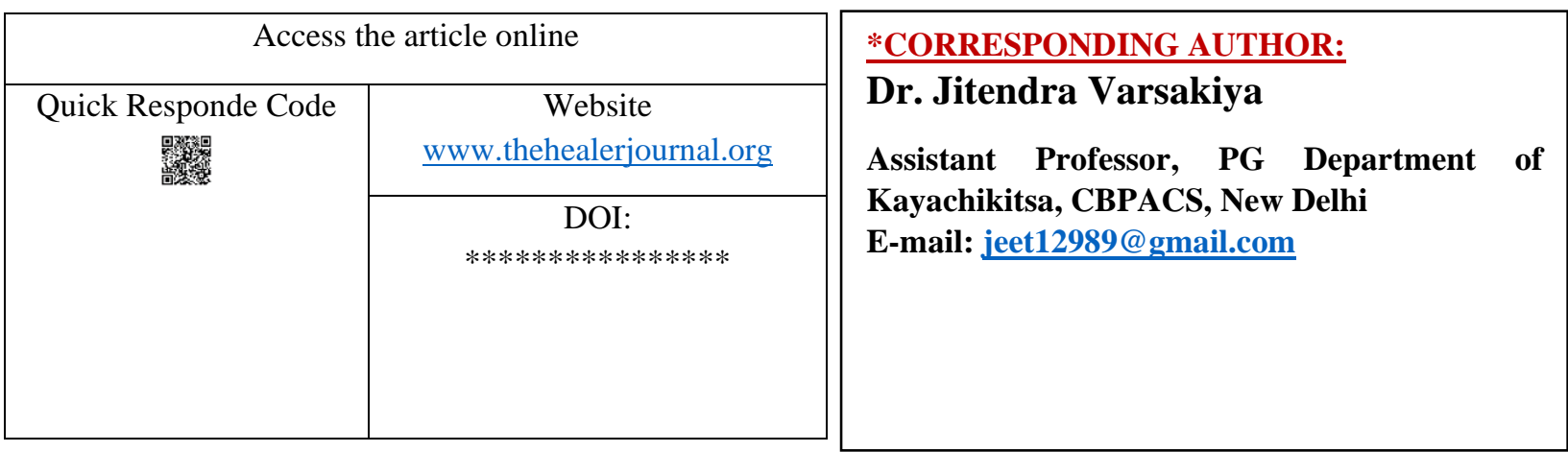

\section{References:}

\footnotetext{
${ }^{1}$ Vaidhya YU, editor. Commentary Vihyotini of Atridev Gupta Astanga hridayam of Vagbhata, Sutra Sthana. Ch. 3., Ver. 8. Varanasi: Chaukhambha Prakashan; 2014. p. 59.
} 
${ }^{2}$ Acharya YT, editor. Commentary Ayurveda Dipika of Chakrapanidatta on Charak Samhita of Agnivesha, Sharira Sthana. Ch. 04, Ver. 13. Varanasi: Chaukhambha Prakashan; 2011. p. 318.

${ }^{3}$ Tripathi B, editor, Shadangdhar Samhita Purva khanda Ch-2, ver.30, 2007, Varanasi, Chaukhmbha Surbharati Prakasna, p.120.

${ }^{4}$ Vaidhya YU, editor. Commentary Vihyotini of Atridev Gupta Astanga hridayam of Vagbhata, Sutra Sthana. Ch. 3., Ver. 58. Varanasi: Chaukhambha Prakashan; 2014. p. 69.

${ }^{5}$ Vaidhya YU, editor. Commentary Vihyotini of Atridev Gupta Astanga hridayam of Vagbhata, Sutra Sthana. Ch. 3., Ver. 8. Varanasi: Chaukhambha Prakashan; 2014. p. 59.

${ }^{6}$ Acharya YT, editor. Commentary Ayurveda Dipika of Chakrapanidatta on Charak Samhita of Agnivesha, Sharira Sthana. Ch. 01, Ver. 109-110. Varanasi: Chaukhambha Prakashan; 2011. p. 197.

${ }^{7}$ Acharya YT, editor. Commentary Ayurveda Dipika of Chakrapanidatta on Charak Samhita of Agnivesha, Sutra Sthana. Ch. 07, Ver. 35-36. Varanasi: Chaukhambha Prakashan; 2011. p. 78. 